（435）オーステナイト采ステンレス鋼の䏶間加工条件と

絬晶粒度の関係

晽神戸製銅所中央研究所。工博井上钤

1. 緒 言

落田義隆，川田昭二

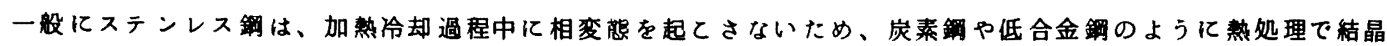

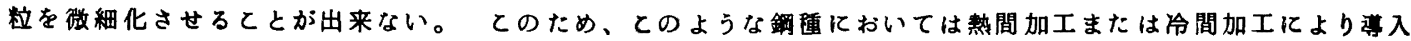
される加エひずみと再結晶現象を利用するのが唯一の微細化方法であるといってよい。

本研究では、SUS 304 ステンレス鉿を供試材として、熱間加工条件を有効に利用して結晶粒を微細化すると とを目的とし、加工温度、加工度などの熱間加工条件と再結䐉、粒成長との関保について基硭的な検討を行なっ た。

\title{
2. 実酫方法
}

SUS304を長さ $100 \mathrm{~mm}$ 、幅 $40 \mathrm{~mm}$ 、厚さ $\mathrm{tmm}(\mathrm{t}$ は仕上り後 $15 \mathrm{~mm}$ となるように調整)の試片とし、

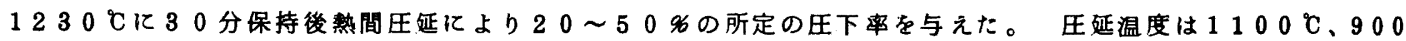
${ }^{\circ} \mathrm{C}$ およ 700 C とし、王延前に所定温度に 10 分以上保持した。迁延後はすぐに水冷したものと、10分、 30 分保持後水命したものについて組織、結晶粒を調べ再結晶挙動を検討した。また水命後再加熱し、再加熱 途中での再結晶举動も調べた。

\section{3. 実䣯結果}

1 ) 压延後、王延温度における経過時間と硬さの変化を第 1 四に示す。700 C 王延では30分以内では再結晶は始ま らず、 900 C 以上では 10 分以内に再結晶が完了している。 2 ) 压延条件（压延温度、圧下率）と再結晶挙動をまとめる と第 2 龱に示すように、未再結晶域 (UR) 再結晶域(R)およ び粒成長域 (G)にわかれる。

3) $7000^{\circ} \mathrm{C} 、 900^{\circ} \mathrm{C}$ 压延後再加熱したときの結晶粒の変化 を第 3 四に示す。 700 C 圧延のときは 850 C で再結晶 が起ころか、このときの結晶粒度は壬下率により著しく異は 万。一方, $900^{\circ} \mathrm{C}$

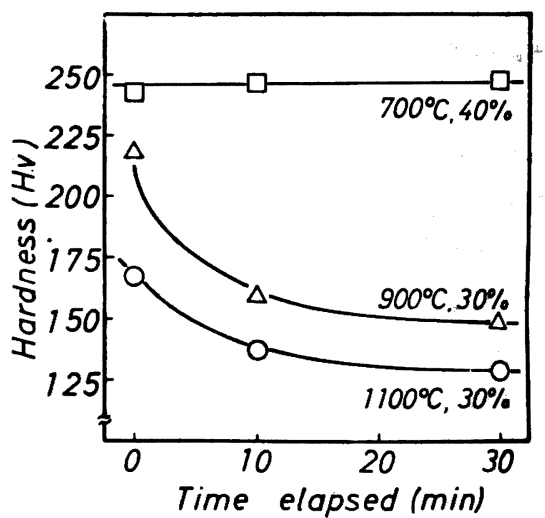

壬延材は結晶粒の Gradual Growth 過程を示していろ。

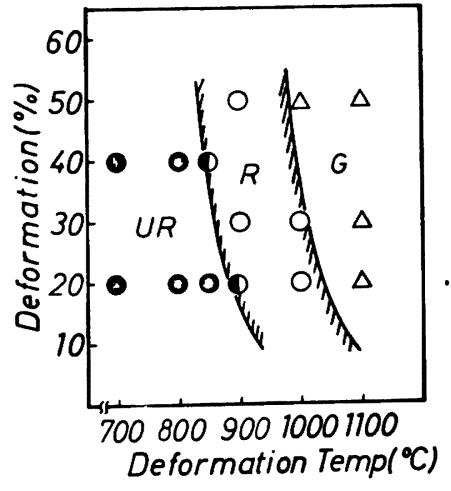

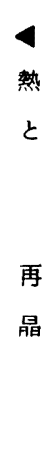


669.15'26'782-196: 669.112.228: 620.172/178: 539.3/4

'78- S 891

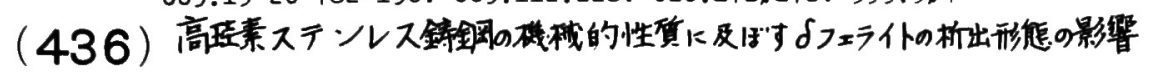

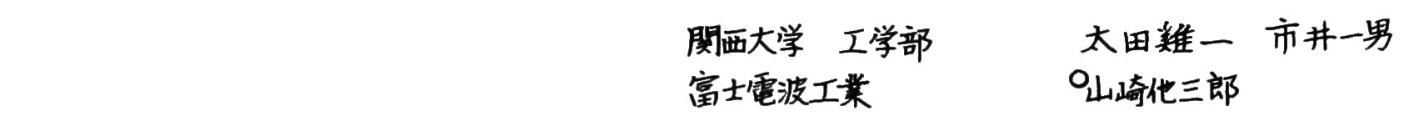

\section{1. 緒言}

オーステナイト系ステンレス鋳銅は溶㭙時の割れ威受性が大きいこと，又，若チフェライを含有す

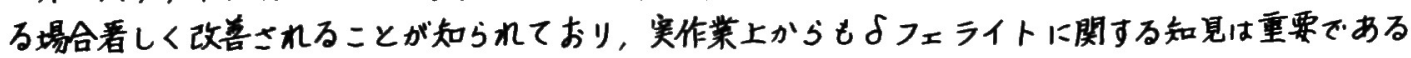

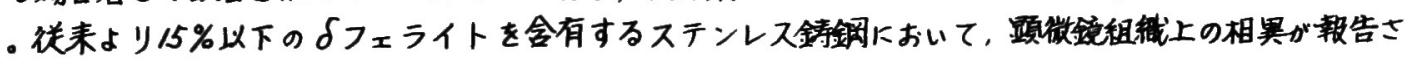
れておりT.Takalo S"は vermicular ferrite と lathy ferriteに分類を行っている。本研究はSi添加により

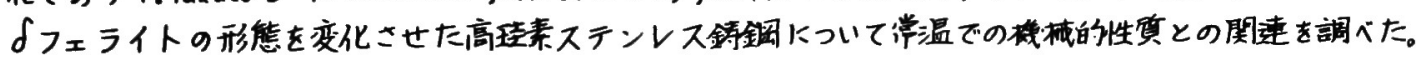
2. 武料 おdび 实隃方法

武料は原材料としてSCS19を使用し，NiおdUＳiを添加して高周波安により50 kg溶解した。化学成分

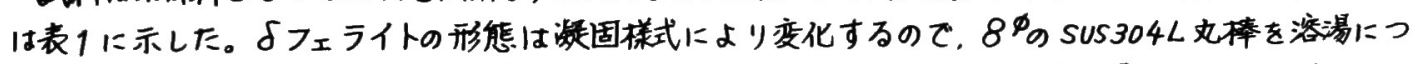

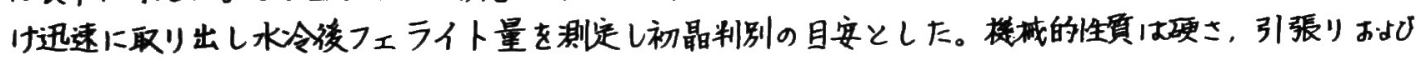
街笔武駼を行った。ঠフェライト現出には15\%境政アルコール を用い,フェライト量はフェライトインジケーターを使用した。

3. 实騟結果おdび考察

组辅は写真に示したようによフェライトが 5 7.5\%の場合 と $15 \%$ 以上の場合，形状には余少大きな差がるくむしろ存

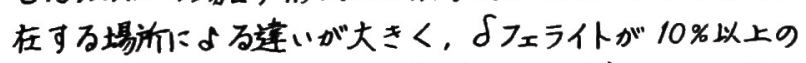
場合の存在場所は元のフェライト粒內に限定士れ，粒界に は現ゆれ‘いのが特微である。二の变化卓は合金元素に関 係されないと考えうれT.Takalo5の結果と一致する。

强度は回1に示すとおり反フェライトの增加に伴い单调に

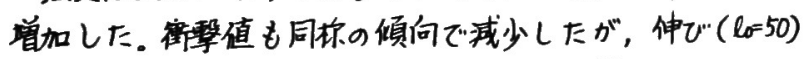
はフェライト量よりフェライトの存在状態の影㫫によりおよ光 5 15\%の䡉田で变化世ず，強度の山增加する現象が見う れた。ニれは写真に示すようにオーステナイトがフェライト をとリ囲んだ形をしていることによる粒界の効果によるも のと考えられる。

表1 試料の化学成分 $(\%)$

\begin{tabular}{|c|c|c|c|c|c|}
\hline 特号 & $C$ & $S i$ & $M_{n}$ & $N i$ & $C r$ \\
\hline 3 & 0.03 & 3.4 & 0.6 & 12.7 & 18.2 \\
\hline 4 & 0.03 & 4.3 & 0.6 & 12.6 & 18.2 \\
\hline 5 & 0.03 & 5.2 & 0.6 & 12.7 & 18.2 \\
\hline
\end{tabular}

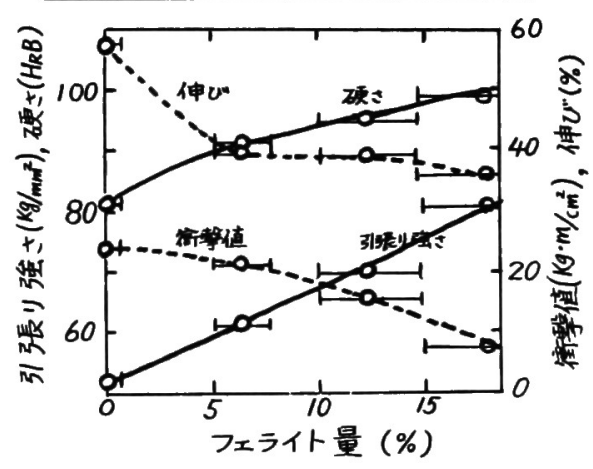

图1フエライト量と栰械的性筫の関係

1) T. Takalo, N.Suttala and T. Moisio: Met. Trans.. 7A (1976), P1591

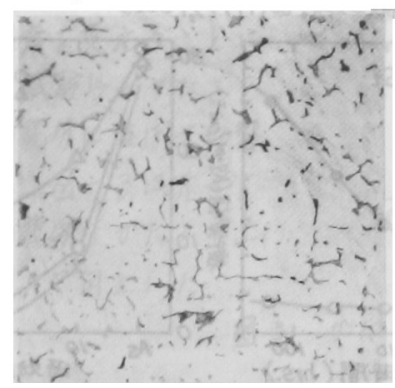

武料3 F: 5 7.5\%

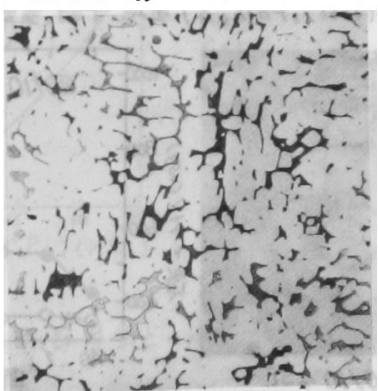

武料4 F: 10 15\%

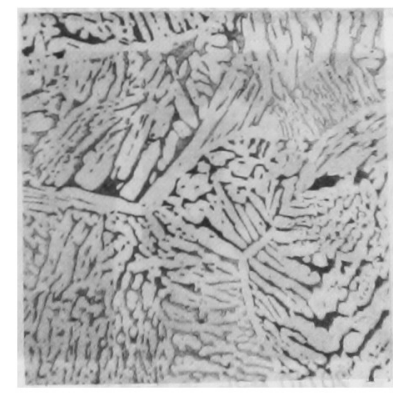

武料5 F： $>15 \%$ 


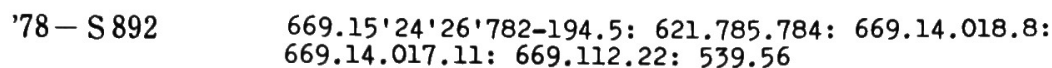

(437) 二相ステンレス銅の熱她理に関する研究为5 㫰

$475^{\circ} \mathrm{C}$ 脆性

閔西大学工学部落一。市井一男

\section{1、緒言}

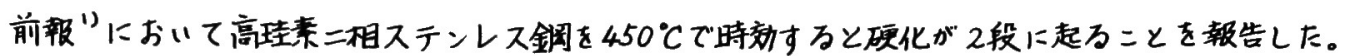

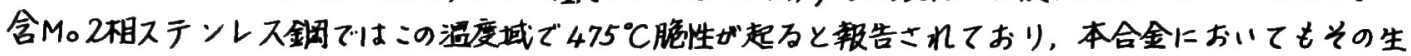

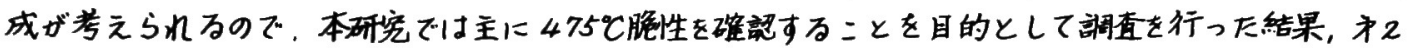

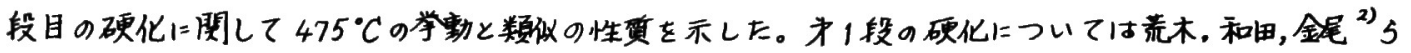

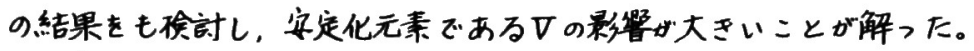

\section{2. 实跨方法}

試料は高周非泳解により得た前曰と同じものを使用し20/1045iおdU゙/6/64Si二相合金について調

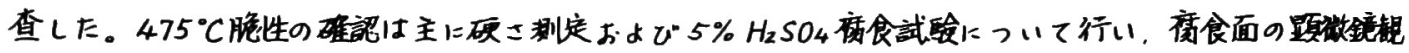
察により行った。

\section{3 实駼結果 万よび考察}

フェライト相の硬さは四エに示すように2段に起りオーステナイト相では硬化は起うなかった。30\%Cr 铜の $475^{\circ} \mathrm{C}$ 脆性は $5 \% \mathrm{H}_{2} \mathrm{SO}_{4}$ の腐食度を减少するといわれているぶが，本合金においても同标の現象が 見うれ，为2段の硬化に伴いフェライト相の腐食度が咸少し写真 2 に示すように，ガルバニッフ効果に より溶体化の場合とは逆にオーステナイトが盗块的に溶解しているのがわが。更にフェライト相に粒

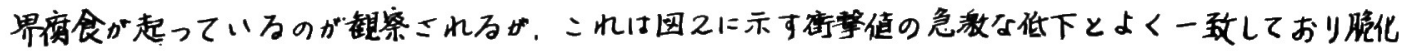

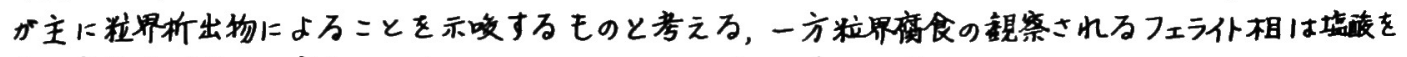

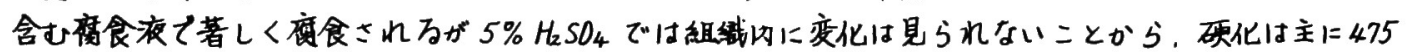

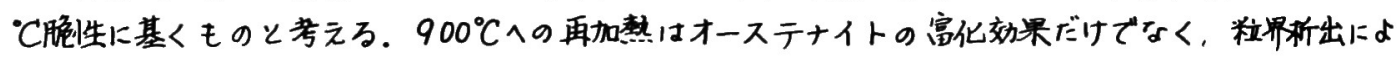
る脆化の防止に効果があると考えられる。

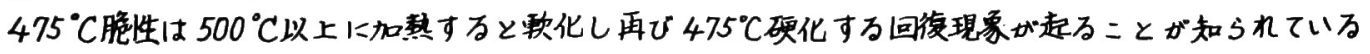

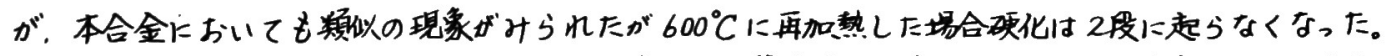

才、段の呼化で回復現象が見られたこと，荒木らの潜优期と一致すること，、を含有している合金で

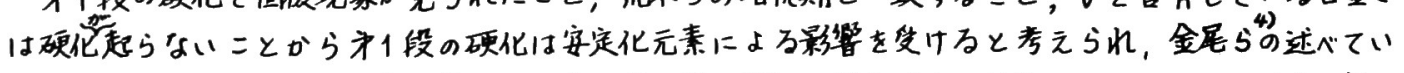

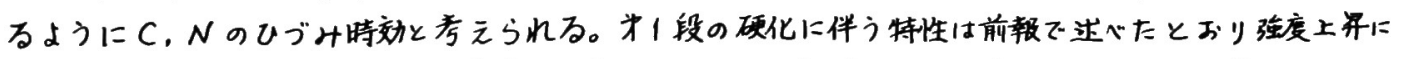

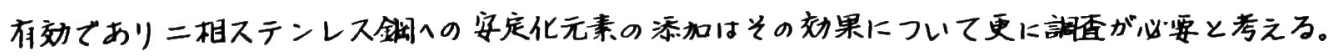

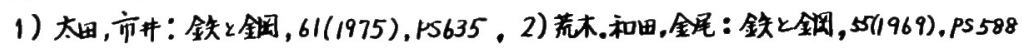

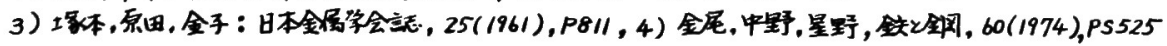

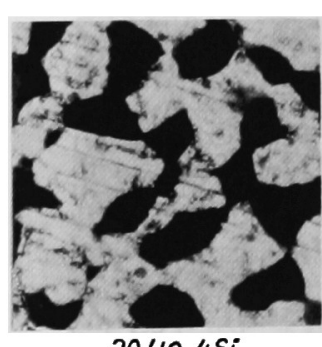

20/10 4Si

写真 $11050^{\circ} \mathrm{C}$ 溶体化

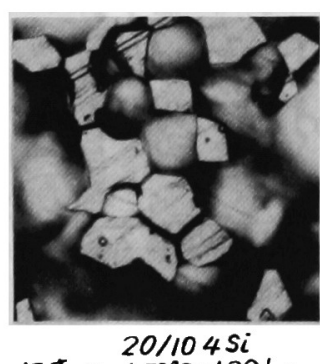

写真2 $450^{\circ} \mathrm{C} \times 128 \mathrm{hrs}$.

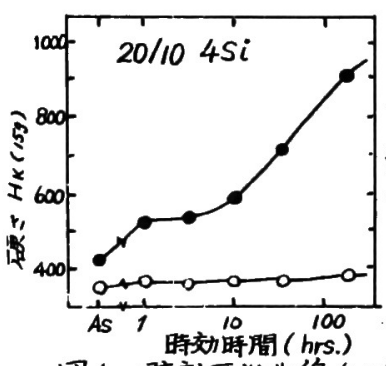

因1時効硬化曲線 $\left(450^{\circ} \mathrm{C}\right)$

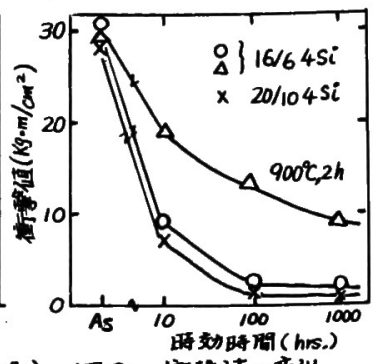

园2 㣫学磌の变化 


\section{1. 船言}

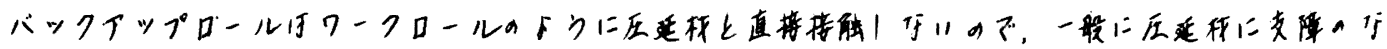

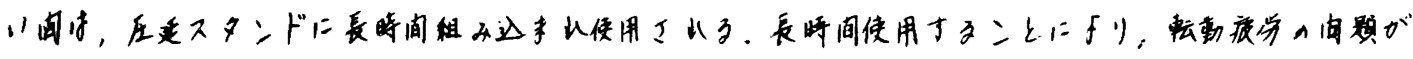

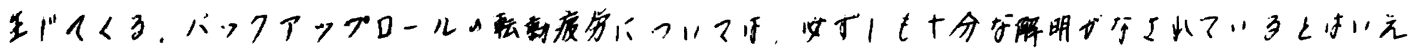

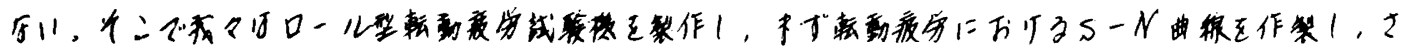

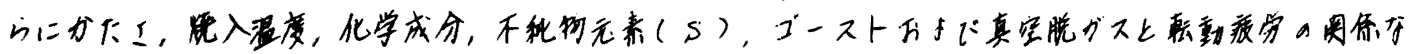

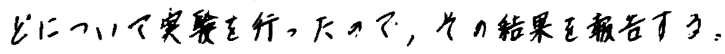

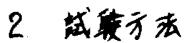

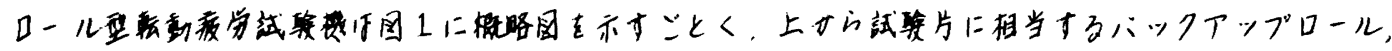

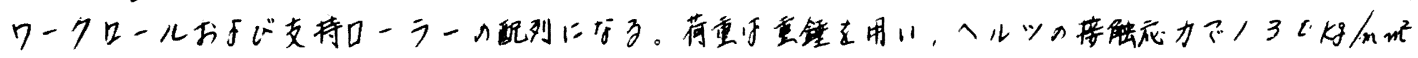

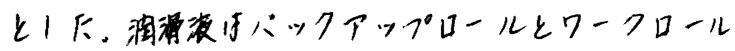

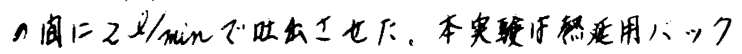

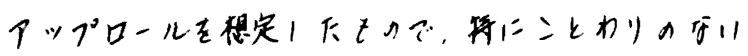

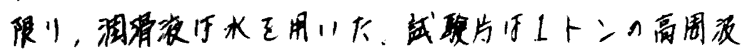

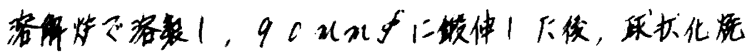

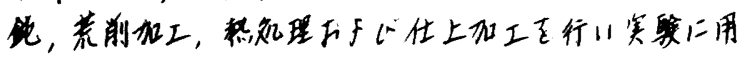

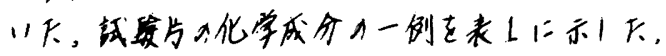

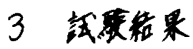

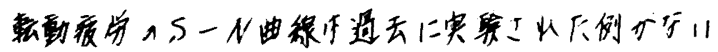

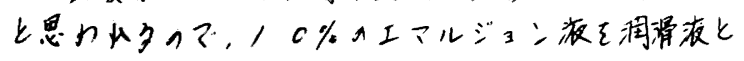

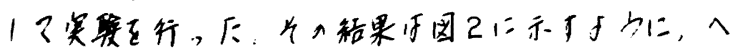

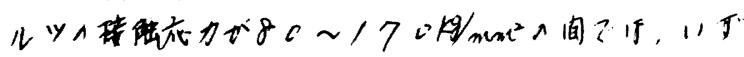

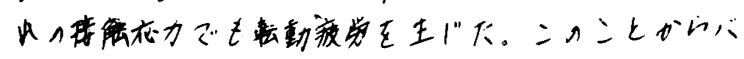
ッフナップロールホ实绦に

使用さいる埸合，ワークロ

ールとムヘルッカ磁底力

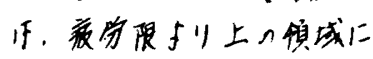
ちると考方的る。

烧房温度を变元ることに

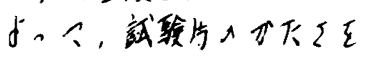

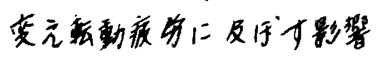

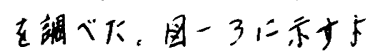

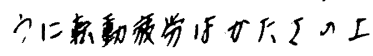
易に先例1て向上人厂。
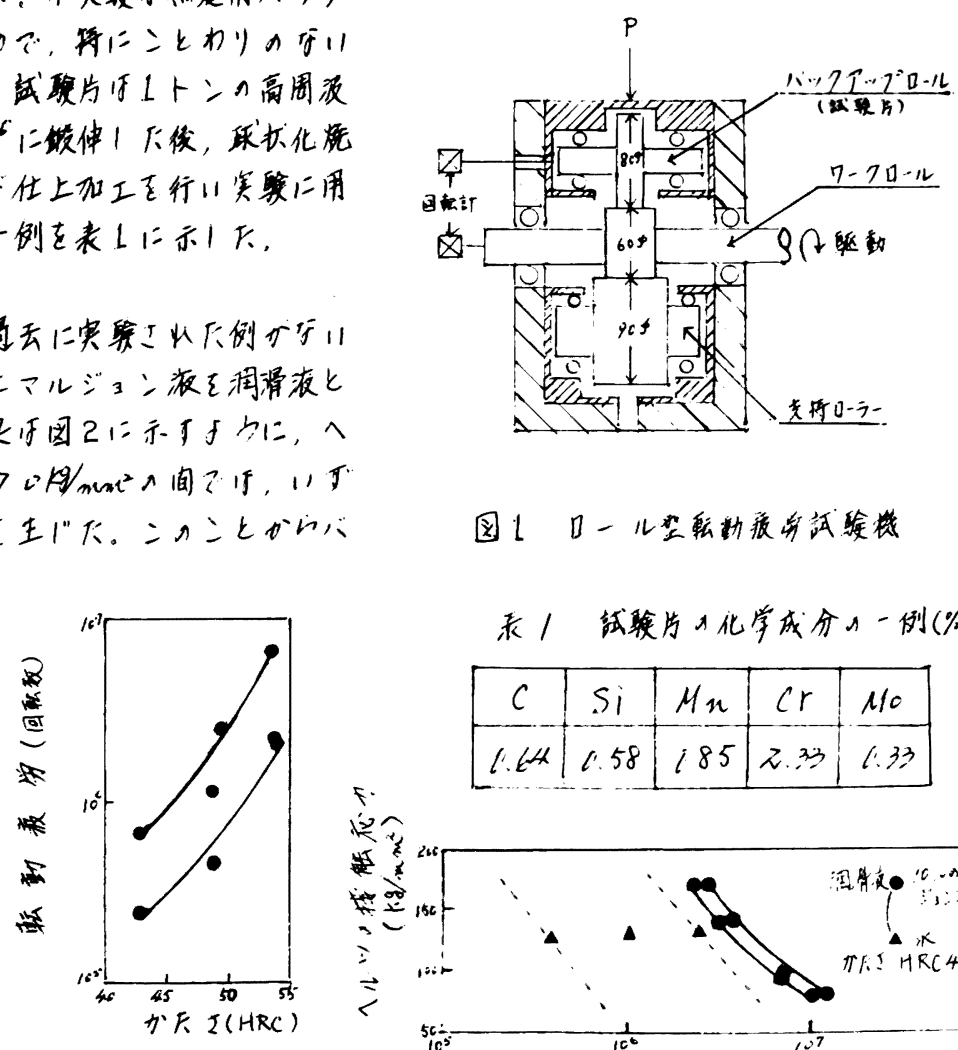

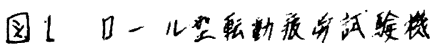

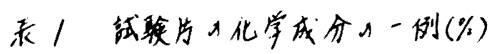

\begin{tabular}{|c|c|c|c|c|}
\hline$C$ & $S i$ & $M n$ & $C r$ & $M 10$ \\
\hline $1.6^{44}$ & 0.58 & 185 & 2.33 & 0.33 \\
\hline
\end{tabular}

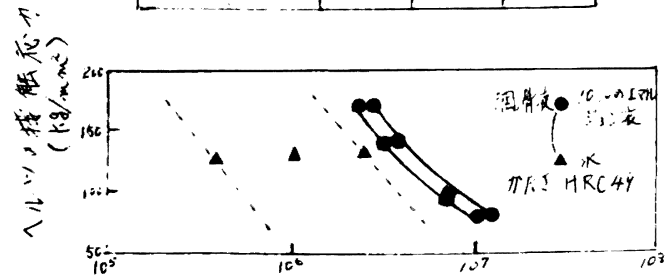

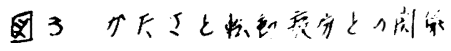
檕到着分(国输)

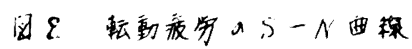


(439) パックアップロール材の転動疲学き裂発生寿命におよはす未溶解炭化物 およひ基地の影響

神戸製鋼所中央研究所太田定雄。高島孝弘

溝口孝遠吉川一男

1. 緒言 バックアップロールの特性としては、耐摩耗性と耐スポーリング性に優れていることが要求さ れる。前報にれおいて、耐摩耗性におよはす $\mathrm{C}$ 量の効果存炭化物と基地の $\mathrm{C}$ 量に分けて検討し、岸化物の量、 寸法の增大、基地 $\mathrm{C}$ 量の増大ともに耐摩耗性に有効であるととを明らかにした。スポーリングは、転動疲労あ るいは熱衝撃によるき裂の発生と、こ㧈の伝播の過程とからなる。本報告では、とのうち転動疲学さ裂発生寿 命に対する $\mathrm{C}$ 量の効果支検討し、 $\mathrm{c}$ 量の增大は、転動疲労き裂発生寿命に 対しても有効であることを見出したので報告する。

2. 実験方法武験材は前報と同様である。表 1 に鋼種と熱処理条件等 を示したが、武験材の硬さはHv500とした。試験は西原式転動摩耗武験 機支用い、武験材と冷延ワークロール材（ $0.85 \mathrm{C}-3.5 \mathrm{Cr}, \mathrm{Hv} 880$ ) リ ングの組合せで、滑り率 $9.1 \%$ 潤滑油 $5 \%$ × ルジョン,ヘルッの最大 接触応力 $\mathrm{Pmax} \quad 140 \sim 200 \mathrm{~kg} / \mathrm{mm}^{2}$ で行はつた。ピッティング寿命は、摩 耗減量の急激な上昇、および表面ピットの状況から决定した。

3. 実験結果因1にピッティング寿命と $\mathrm{c}$ 量の関保を示す。ヘルッの 接触応力 $\mathrm{Pmax} 160 \mathrm{~kg} / \mathrm{mm}^{2}$ で、かなり苛酷子場合に相当する。 ピッティング寿命は $\mathrm{C}$ 量とともに上昇するが、0.3，0.45\% c 鋼は、末 唂解炭化物はなく寿命は短いが、0.6\% C 以上では炭化物があり寿命の上 昇が著しい。0.6\%以上に0 量が増加してもあまり寿命は改善されない。 写真 1 は、比較的初期の転動表面の状況であるが、炭化物のない場合には、

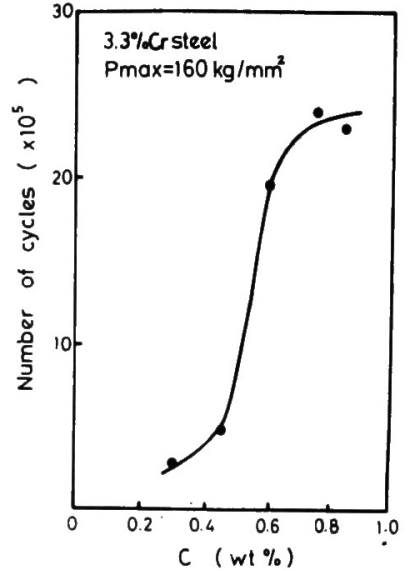

困 1.ピッティング寿命におよはす C 量の影䪪 凝着摩耗でとり去られた部分の近傍には、かなり 大さな望性流動域が られるのに対し、炭化物の 存在する場合には塑性流動域が小さい。くり返し 応力場で、炭化物を含まない低 C 銅が、塑性振巾 が大きいので早期にピッティングがあらわれたも のと考えられる。写真 2 に試蛤片に生したピッテ ィングの例を示す。転動方向に末広からの扇形を している。 $0.8 \% \mathrm{C}$ 鋼については、炭化物の平均 粒经 $0.67,0.84,1.07 \mu \mathrm{m} の 3$ 種間には君命の 差は認められはかった。又 Mo，Vの添加材につい ても検討した。

1) 太田, 高島, 溝口 吉川，鉄と銅 64 ( 1978 ) s 237

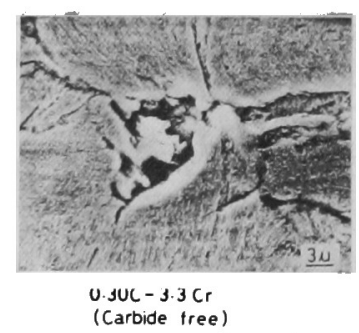

写题 1 転動焉面状况

表 1. 供試材の䓡処理

\begin{tabular}{|c|c|c|c|c|c|}
\hline 鋼名 & 鋼種 & $\begin{array}{c}\text { 焼入温夏 } \\
\left({ }^{\circ} \mathrm{C}\right)\end{array}$ & $\begin{array}{c}\text { 扊华物 } \\
\text { 体監率 } \\
(\%)\end{array}$ & $\begin{array}{c}\text { 焼庆温复 } \\
\left({ }^{\circ} \mathrm{C}\right)\end{array}$ & $\begin{array}{l}\text { 硬 き } \\
\mathrm{H} \mathbf{v}(\mathrm{BO})\end{array}$ \\
\hline$A_{\mathbf{f}}$ & $0.30 \mathrm{C}-3.3 \mathrm{Cr}$ & 930 & 0 & 270 & 496 \\
\hline$B_{f}$ & $0.45 C-3.3 \mathrm{Cr}$ & 930 & 0 & 500 & 502 \\
\hline C & $0.60 \mathrm{C}-3.3 \mathrm{cr}$ & 930 & 0.7 & 500 & 496 \\
\hline$c_{f}$ & $0.60 \mathrm{C}-3.3 \mathrm{Cr}$ & 990 & 0 & 510 & 502 \\
\hline D & $0.75 \mathrm{i}-3.3 \mathrm{Cr}$ & 930 & 2. 9 & 500 & 502 \\
\hline $\mathrm{E}$ & $0.85 \mathrm{c}-3 \mathrm{Cr}$ & 930 & 2. 9 & 510 & 505 \\
\hline $\mathrm{F}_{\mathrm{f}}$ & $0.60 \mathrm{C}$ & 930 & 0 & 490 & 496 \\
\hline$G_{f}$ & $0.60 \mathrm{C}-2.0 \mathrm{Cr}$ & 990 & 0 & 490 & 493 \\
\hline
\end{tabular}

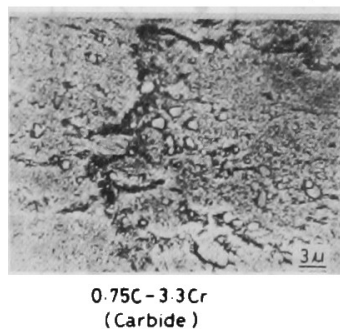

(Carbide)

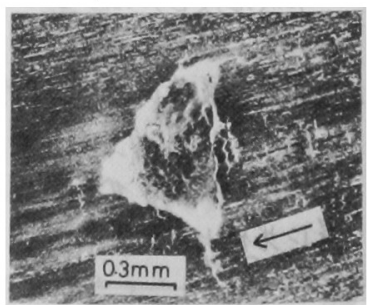

写真 2 武験片てのピッティング （矢印仙転動方向） 
1. 踷 言

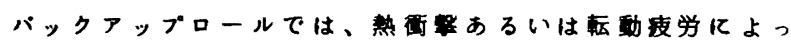
て生した砤細なき裂がロールの枟動中に层播し、スポーリン グを生しるととがる。前報ではとのスポーリングにっいて 力学的解析を行い、スポーリングき裂の层播寿命にはロール 材の支労き裂云播特生が大さく影整していろとと、およびス ポーリングき裂の停止梁さは破壊甠により支配されている ととを明らかにした。近年ハックアップロール材として耐摩 耗生改善のために高 $\mathbf{C}$ 材が使用される倾向にあるか、、 $\mathrm{C}$ 量を 増したためにスポーリングに対する特甡が劣化することは避 けねばならないるととで今回は C 量を変え、またMo，Vを添 加した籍種について実検を行い、耐摩耗性を損わす波学き裂

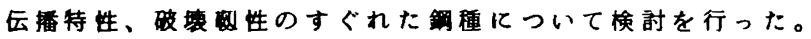

\section{2. 実䀫方法}

洪試金の化学成分を表 1 亿示す。試䀫材は容解、錹造、球

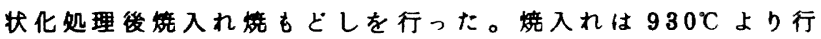
い、焼入れ後の組織はすべての銅種で完全マルテンサイトに

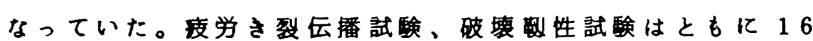
mm厚の C T 試殹片を用いて行った。

\section{3. 実醶結果}

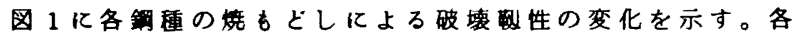

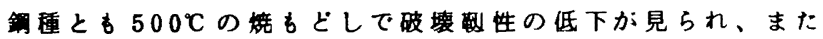
同一の焼ちどし温度ではＣ量の低いほど高い牲を示す。し かし烍もとしによろ硬度の低下の程度は鋼種により異なり、 同一硬度での破壊性を比較した場合、必すしもC量の低い ほど路は高くならない。たとえばバックアップロールの表 面硬度 Hv500（ロール喚算 H868）での破壊制を比較する と、最も高い瑨もどし温度のとれる $0.8 \mathrm{C}-3.5 \mathrm{Cr}-\mathrm{Mo}-\mathrm{v}$ が最 高の性值を示す。因2 亿各銅種のHv500亿おける波学き裂 层播特性を示す。スポーリングき裂层播寿命に大きな影郘を 与光ろ $\Delta \mathrm{K} 20 \sim 40 \mathrm{~kg} \cdot \mathrm{mm}^{-8 / 2}$ の領域での疲爫さ裂云播速度 についても、H、500で最も破壊制の高い $0.8 \mathrm{C}-3.5 \mathrm{Cr}-$ Mo-Vが最も良い特性を示す。他の鋼種の疲労さ裂云播特性 はほは同しであり、特に $\mathrm{C}$ 量の相違による疲学き裂云播特性 の差は認められない。
1) 太田，洗口，高島
鉄と鋼 $64,4,236$

\begin{tabular}{|c|c|c|c|c|c|c|c|c|c|}
\hline & $\mathrm{C}$ & $\mathrm{Si}$ & $\mathrm{Mn}$ & $\mathrm{P}$ & $\mathrm{S}$ & $\mathrm{Ni}$ & $\mathrm{Cr}$ & $\mathrm{Mo}$ & $\mathrm{V}$ \\
\hline $\mathrm{I}$ & 0.45 & 0.45 & 0.78 & 0.016 & 0.012 & 0.18 & 3.53 & 0.49 & 0.00 \\
\hline 2 & 0.62 & 0.58 & 0.83 & 0.015 & 0.005 & 0.41 & 3.00 & 0.39 & 0.07 \\
\hline 3 & 0.71 & 0.60 & 0.68 & 0.007 & 0.000 & 0.11 & 4.59 & 0.51 & 0.11 \\
\hline 4 & 0.78 & 0.37 & 0.83 & 0.023 & 0.010 & 0.11 & 3.55 & 0.36 & 0.08 \\
\hline 5 & 0.03 & 0.57 & 0.77 & 0.016 & 0.011 & 0.11 & 3.29 & 0.39 & 0.13 \\
\hline 6 & 0.86 & 0.47 & 0.48 & 0.021 & 0.016 & 0.43 & 3.64 & 0.99 & 0.09 \\
\hline 7 & 0.80 & 0.56 & 0.80 & 0.010 & 0.010 & 0.11 & 3.58 & 0.84 & 0.30 \\
\hline
\end{tabular}

表 1. 化学成分

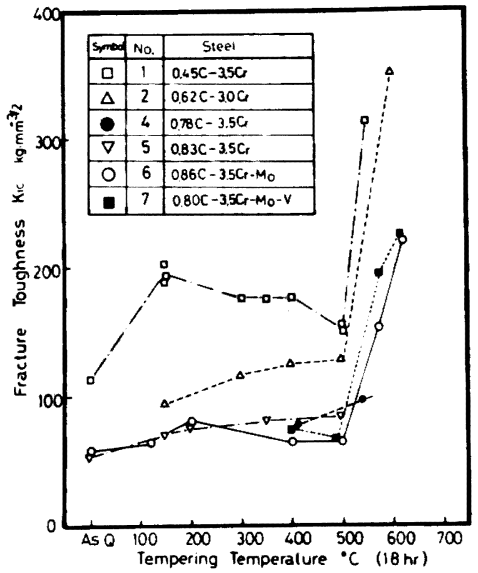

図1. 焼もとし温度と破壊䇝性值

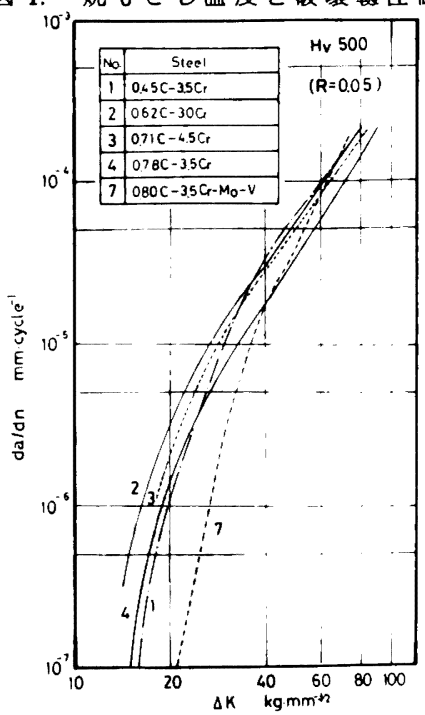

因2. 疲労き裂云播特性 


\section{I 緒 言}

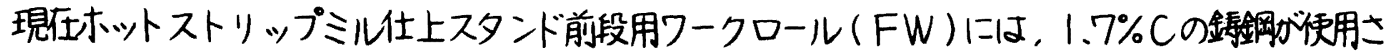
れている。この柈は，非常に安定して使用されているが，最近の圧延技術の進步に対応するため，耐 摩耗性を格段に向上させだ，という要求に対しては，不十分である。

高C鎋鉄ロールは，FW用としてはヨーロッパにおいてはじめて使用され，良い成積をあげた，とい うことで日本と紹介された。しかし日本とヨーロッパではFWに対する要求には差があると考えられ， これがそのまま使用できるとは考えられていが，耐摩耗性が良いことが予想され，二の意味て興味を持

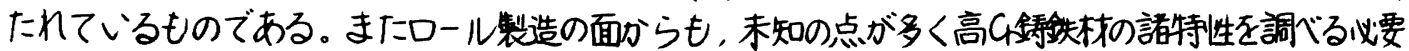
があり以下の諸特性を矵定した。

\section{II 高C、金敘材の諸特性}

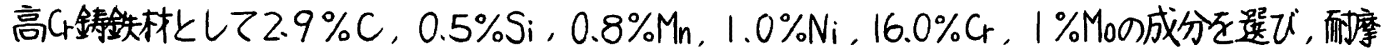
耗性，变態特性，弾性奉，引張强さを調へた。以下にその結果を示した。而摩耗性は120"コランダム

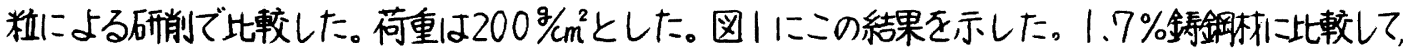

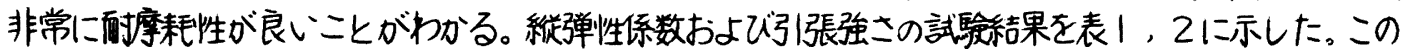
值は鋼の值よりも大きく諸応力の検討には，鋳鉄というよりは䞒として扱うべきことがわかる。ロール 製造の上からは变態特性を知る必要がある。一例を图2に示した。

表 1 絎弹性係数の比較

\begin{tabular}{|c|c|c|c|}
\hline & 高Cr鋂铁 & 強勒全輩失 & 545 \\
\hline $9 \mathrm{~mm}$ & 22,000 & 12,000 & 21,000 \\
\hline
\end{tabular}

表2 高C、金契鉄口ールの引張強さ

\begin{tabular}{|c|c|c|}
\hline & 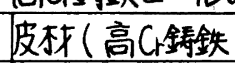 & 心゙材（強勒䤻金失） \\
\hline 引張強士 & 58 & 22 \\
\hline
\end{tabular}

\section{III 高CFWロール}

上記諸特性值その他を測定し，それらをもとに，遠心鋯造法により複合FWロールを製造した。製造 時の残留応力は，図2に示すように，皮材のパーライト变態がジく長時間側にあるため，低温域でのべ 一ナイト变態およでマルテンサイト変態よより，皮材か䏽脹する一方，以林高温域でパーライト变態 をおこすため,ロール表面には圧縮応が残留し，さらにニれに，冷却時の鶖们が加算され，表にに 示すように，弾性係数が大きいこととめいまって，比較的大きた值とるる。ニれは高温の烧戻しによっ

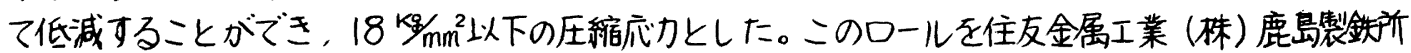
にてFWロールとして使用したところ，図ろに示すように格段の高耐摩耗性と示した。

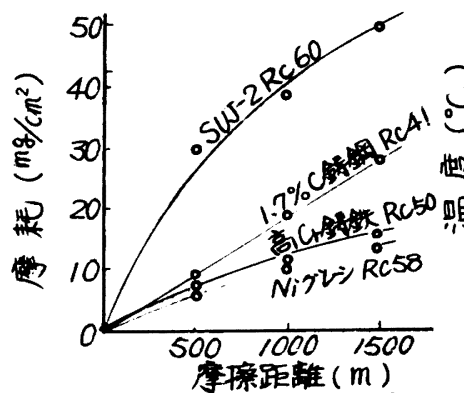

図1各種口ール材の耐摩耗性

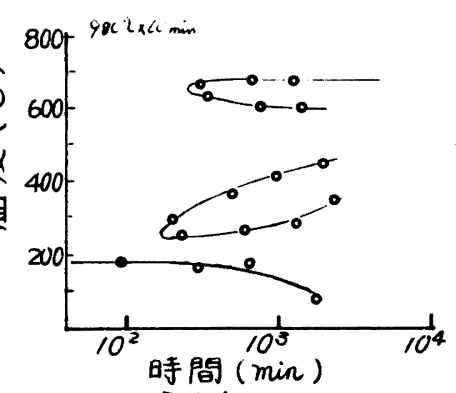

図2 高C釾鉄のCCT曲楾

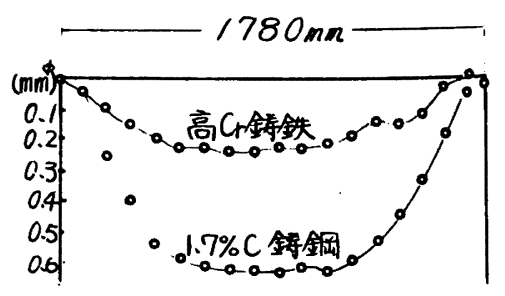

困了 FWロールの摩耗パターン 